\title{
TRANSLATING RHYTHM INTO THE RHYTHM OF TRANSLATION
}

\begin{abstract}
:
This paper proposes that Meschonnic's writing, and particularly his writing on translation, does not do justice to the richly suggestive conceptual framework he constructs around the notion of 'discourse'. It is perhaps peculiarly translation, at least in the version canvassed here, that reveals what is insufficiently developed and too defensively protected in Meschonnic's thinking about discourse, rhythm and related concepts. This is, then, an attempt to better understand, within a critique of Meschonnic's albeit wonderfully enriching vision of translation, not only what distinguishes rhythm as it acts in discourse, from rhythm as it acts in translation, but also what rhythm's relation with orality and vocal values is, and how translation might translate across those values.
\end{abstract}

There are few readers of Henri Meschonnic who have not been deeply persuaded by his attack on the various critical dualisms inherent in the linguistic sign, and equally persuaded by his own alternative, and integrative, account of discours. His work has, quite properly, been hugely influential. But what the title of this paper is meant to suggest is that Meschonnic's critical stance is over-integrative, particularly in relation to translation, that rather than translation's being the site of the affirmation of the poetics of discours, to replace the protocols of langue ${ }^{1}$ discourse must acknowledge its inadequacy in the face of a writing - translation - that exceeds and subverts it.

Meschonnic's argumentative strategy is that of the browbeater, an unrelenting reiteration of a position which is hugely suggestive but non-interlocutory and non- 
progressive. The reasons for this lack of progression seem to me to be threefold. First, his settling back into a quasi- synonymic chain of concepts - discours > rythme > oralité > historicité > énonciation > le continu > récitatif ${ }^{2}-$ whose terms tend to collapse into each other, to generate tautological closure, and whose mesmerising litany excuses him from making critically demonstrable what is conceptually so invigorating. ${ }^{3}$ Second, he falls prey to the paralysis of his own critical mapping, which allows little nuancing of its topographical features. Thus Walter Benjamin, for all the richness of his reflections on the task of the translator, ${ }^{4}$ for all Meschonnic's conceding that he at least imagines translation as 'un entreles-langues' ('a between-the-languages'), is once and for all tarred with the brush of 'la théologie du génie des langues'5 ('the theology of the genius of (national) languages'). Third, on the evidence we have, Meschonnic's own critical imagination does not do justice to what his theoretical framework makes possible, partly because, whatever he implies to the contrary, he clings to a centripetal way of thinking about discourse.

It is this last charge I wish to concern myself with, particularly as it relates to the way we think about rhythm in the translational enterprise, and without further ado I will enumerate some of my quarrels with Meschonnic's method:

(i) He gives insufficient room to the process of reading, indeed to the historicity of the reader, insistent though he is on the historicity of each translation.

(ii) He prevaricates about the nature and function of the reading voice, particularly about its function as an epistemological instrument, even though he pays much attention to the anthropology of voice.

(iii) Relatedly, he does not clearly distinguish between linguistic acousticity as pure IPA sound and as laryngo-buccal articulation. And what exactly, for Meschonnic, is the unit of pronunciation: phoneme? syllable? word-group? 
(iv) He does not directly address the ways in which movement operates and is perceived in language, even though movement, for him, is central to the being and becoming of discourse.

(v) His translational criticism and text-analytical methods fall short of his theoretical thinking.

(vi) He fails to develop his proposals about the corporeality of language (in orality), and about the relationship of the oral and the visual. It is true Meschonnic has suggestive things to say about the voice and the visual: 'La voix, qui peut faire sa syntaxe, sa rythmique, peut faire sa typographie. C'est pourquoi une poétique de la typographie, et du visuel, loin d'être étrangère à l'oralité, peut montrer la relation entre l'oral et le visuel. Et la faire"6 ('The voice, which can generate its own syntax, its own rhythm, can equally generate its own typography. That is why a poetics of typography, and of the visual, far from being alien to orality, can show the relation between the oral and the visual. And generate it'). But these proposals are hardly developed beyond a fruitful preoccupation with the uses and translational abuses of punctuation.

Furthermore, he does not care to envisage the text as a material object in the real world.

(vii) His notion of discourse privileges accent, even over-accentuation. In this, he declares a kinship with Gerard Manley Hopkins, whose 'sprung rhythm', one might just add, he translates, in his book with Gérard Dessons, as 'rythme jaillissant' ?

(viii) His translational conduct is constrained by his only having a monoglot reader in mind, even though he knows the price to be paid: 'Naturellement, le lecteur de la traduction n'en sait rien. Et ne sait même pas qu'il ne sait pas. La traduction n'est pas faite pour dénoncer le traducteur. Mais pour le cacher. Le lecteur, sauf celui des éditions bilingues, ne lit que ce qu'on lui donne à lire. Il lit du sens" ('Naturally the reader of 
the translation knows nothing of all this. He doesn't even know that he doesn't know. The translation has not been made to denounce the translator. But to hide him/her. The reader, aside from the reader of bilingual editions, reads only what he/she is given to read. He/she reads for meaning').

I have suggested that these shortcomings relate to Meschonnic's centripetal attitudes to text. By 'centripetal' I mean that discourse is self-regarding, self-reflexive, ${ }^{9}$ in full possession of its expressive means (in Meschonnic's terms, rhythm and prosody), consistent with itself, organic (in Meschonnic's terms, systematic), and enjoying a stable literariness. From the translational point of view, there is something undeniable to preserve. In affirming that the poem makes the poet and makes the language, rather than vice versa, Meschonnic safeguards discourse as the rhythm of a subject, against appropriation by a psychophysiological subjectivity, and ensures that discourse has both cohesive authority and linguogenerative plausibility. My argument is that translation cultivates centrifugal attitudes to text. Centrifugal translation starts out from the assumption that the source text is constantly in search of itself; that it does not comprehend itself; that it has yet to fulfil itself, in paralinguistic realisations, in intersensory explorations; that it does not own its literariness, but rather that its literariness is unstable, continually re-inventable, always at the text's widening periphery. Through processes of translation, the source text proliferates performatively. Translation thus attracts what Meschonnic outlaws: the inserted, the inconsistent, a heterogeneity of tones, registers, formal resources. ${ }^{10}$ Thanks to the polyglot reader, translation stands in relation to its source text and, by that same token, compels the source text to stand in relation to it, to justify itself by that relation. ${ }^{11}$ Translation activates ongoing textual reciprocation between source text and target text. This is to say that Meschonnic does not properly honour his own distinction between translation as 'transport' and translation as 'rapport'. ${ }^{12}$ 
I want to speak a little of this centrifugality as a text-inherent characteristic of translational reading, in relation to Meschonnic's commentary on French translations of Meng Hao-ran's 'Aube du printemps'. Of the version that appears in the Paul Demiéville Anthologie de la poésie chinoise classique (1962) :

Au printemps le dormeur, surpris par l'aube, Entend partout gazouiller les oiseaux.

Toute la nuit, bruit de vent et de pluie:

Qui sait combien de fleurs ont dû tomber.

Meschonnic writes:

Mais la présentation typographique, qui veut suggérer des vers (avec la majuscule initiale de convention), et même un quatrain, n'est pas portée par un rythme métrique correspondant: des assemblages qu'aucune contrainte métrique immédiatement sensible n'invite à lire comme des décasyllabes même s'ils ont dix syllables - mais on sait qu'il ne suffit pas de 'dix' syllables pour faire un décasyllable... Il aurait fallu que le premier vers soit 4-6 alors qu'il est 6-4; le troisième invite à une diction du parlé; du coup le quatrième, qui pourrait être lu comme un 6-4 n'a plus de métrique sensible. Ce qui montre bien qu'une métrique n'est pas seulement la structure d'un vers, mais une contrainte d'ensemble. Faute de quoi elle est pratiquement inexistante. ${ }^{13}$

(But the typographic presentation, which seeks to suggest lines of verse (with their conventional initial capitals), and even a quatrain, is not sustained by a corresponding metrical rhythm: collections of words which no immediately perceptible metrical 
constraint invites the reader to read as decasyllables even if they each have ten syllables - but we know that 'ten' syllables do not necessarily make a decasyllable... The first line would have needed to be $4-6$, whereas it is $6-4$; the third invites a common-speech delivery; as a result, the fourth, which might be read as a 6-4 loses any perceptible metre. Which all goes to show that a metre is not only the structure of the single line, but an overall constraint. Without which metre is practically nonexistent).

I find it very difficult to square Meschonnic's implicit subscription to a logic of choice, among pre-existing forms, and even to an obligation of choices, with any theory of discourse. Why should one say that a sequence of ten syllables is not sufficient to constitute a decasyllable, rather than that a line of ten syllables is far more expressively versatile than a decasyllable, remembering Mallarmé's description of the 'new' alexandrine as 'toutes les combinaisons possibles, entre eux, de douze timbres'14 ('all the possible combinations, among themselves, of twelve timbres')? Why should one not suppose that the decasyllable can be taken for granted and thus freely explored without an obligation to regular metrism or the establishment of the sequence by a classic 4-6? Why cannot one read these lines as a 'medley' rather than an 'ensemble'? Why cannot these lines exist as a gamut of variations or as sequences of syllables that tempt the voice to different configurations, rather than as a largely isometric suite? When I consider these four lines, I think that the first line might well be a 6-4 decasyllable, but I think of it also as a 'free' tetrametric decasyllable $-3>3>2>2$ - and, indeed, as a 'free' trimetric one $-3>3>4$. And the same is true of lines 2, 3 and 4, thus:

$$
3>3>2>2 \quad 3>3>4
$$




$$
\begin{array}{ll}
2>2>3>3 & 4>3>3 \\
4>1>2>3 & 4>3>3 \\
2>4>2>2 & 2>4>4
\end{array}
$$

Meschonnic interprets the third line as having a 'diction du parlé' ('spoken-language diction'), which, according to him, undermines the metricity of the line following. For me, line 3 certainly has a more notational, elliptical syntax, but I look upon this as a vocal swerve, demarcating the different conditions of the previous night, 'assimilated' into the poem's diction by the peculiarity of the punctuation mark, the colon: which allows the notational to expand again into a fuller syntax, in the fourth line. One might also say of this third line that it not only indicates a 4-6 classical decasyllable, but flirts with the nineteenth-century 'romantic' 5-5 variant:

Toute la nuit, bruit//de vent et de pluie:

which creates a dramatic contre-rejet at the caesura, but in so doing dramatizes the acoustic immediacy of the /५i/ hand-on (nuit > bruit), then echoed and closed in /plui/. So, while the first two lines assonate in /o/ $(/ \mathrm{ob} / / \mathrm{wazo} /)$, the third line encircles its own triple rhyme/assonance, which the final line, more faintly perhaps, imitates in /õ/ (combien, ont, tomber). Meschonnic does not allow for any of this, he has other axes to grind. But what we have here is in fact a translational decasyllable, what Meschonnic might call a 'similidecasyllable', a decasyllable of the kind used by André Markowicz in his translations of Macbeth and Othello, and the decasyllabic equivalent of the alexandrines used by other translators of Shakespeare (Pierre Leyris, Armand Robin, Pierre Jean Jouve) or of Yves Bonnefoy's French Shakespearian hendecasyllable. 
Meschonnic's own version is an exciting departure in the thinking of verse-structure:

printemps qui dort ne sent soleil qui monte
partout partout des cris d'oiseaux s'entendent
la nuit qui vient le vent la pluie leur voix
des fleurs qui tombent qui sait combien combien

But, in his pursuit of a two-syllable equivalent of the monosyllabic characters of the Chinese, Meschonnic both indulges in a compensatory tactic, which sounds like a pis-aller, and fails to tell us what he assumes about the treatment of the line-internal mute e: is 'qui tombent' two or three syllables? I ask particularly, since, in another translation from the Chinese,${ }^{15}$ he clearly treats 'vogue' as a dissyllable. Meschonnic also fails to tell us what he expects in the way of accentuation. Does each group attract a terminal accent, such that the first line here would produce $2>2>2>2>2$, and so on through the poem, until 'qui tombent' (3')?

In place of punctuation, and in keeping with the lay-out of the Chinese characters, Meschonnic introduces spaces. This is a happy way of indicating the refusal of Chinese to declare its grammatico-syntactical hand. But one might argue that while spacing expresses the overall characteristics of Chinese syntactic relating, by the same token it forgoes the localised expressivity of punctuation. And one thing that strikes me about the other French translations from the Chinese is how far colons and points de suspension come into their own as interrogative quizzicalities of relationship and as indeterminate extensions or traversals of semantic space:

$\begin{array}{ll}\text { printemps qui dort... ne sent soleil qui monte: } & 4>4>2 \\ \text { partout: partout: des cris d'oiseaux s'entendent... } & 2>2>4>2\end{array}$ 
la nuit qui vient: le vent la pluie... leur voix: $\quad 4>4>2$

des fleurs qui tombent. qui sait combien: combien...5'>4 $>2$

Punctuation itself is a rhythmicity and also an alternative system of rhymes. What I am struggling to capture, in this 'version' of Meschonnic, is a perceptual variety within certain parameters, the rhythmic activity of the senses, which reflects in the voice in its varying speeds and tones. The full-stop here, in the final line, does not so much indicate an abrupt interruption or termination of falling blossoms, as, rather, the sudden clarity of the inner eye, even as the mind moves into the immeasurable. And the extra phonated e (tombent) provides the rhythmic resonation of inaudible petals, and, paradoxically, makes audible, in anticipation, that full-stop of participating consciousness.

Meschonnic's reflections on iambic pentameter and subsequent analyses of a selection of translations of three of Shakespeare's sonnets $(27,30,71)$ are equally questionable, ${ }^{16}$ partly because of their preconditioned reflexes and partly because of the narrowness of their metrico-rhythmic purview. Among other things, Meschonnic observes that most translators concern themselves more with translating particular metrical forms than with translating poems,${ }^{17}$ ironic in the light of his remarks on the decasyllables from the Demiéville anthology. What most end up doing is translating Shakespeare's iambic pentameters into what Meschonnic disparagingly calls 'simili-vers', and what I am calling translational verse, or metrico-rhythmic translationese, which in this context means verse-lines of a liberated, variable, post-symbolist kind: unreliable in register; resorting periodically to archaism; often under metrical pressure (e.g. omitting articles in the interest of syllable-count); rhyming, assonating or not rhyming; rhyming 'transgressively'; varying rhyme-schemes; indeterminate about the value of mute e's and synaeresis/diaeresis; non-observant of the 'rules' of hiatus 
and caesura - in short, occupying a polymorphous linguistic world, their emphases and focus shifting across different dimensions of textual performance.

Furthermore, Meschonnic's own conceptions of rhythm and prosody as applied in these analyses do not seem to venture beyond patterns of accentuation and syllable for the rhythmic, or beyond vocalic and consonantal couplings (alliteration and assonance) for the prosodic. Nothing to do with segmentation and pausing, tempo or amplitude, enter into rhythmic considerations, and phrasing, intonation, tone, respiratory spans, play no part in prosody, even though intonation and phrasing are integral to the conception of orality. The reason for these omissions is presumably Meschonnic's reluctance to allow voice to disturb the text-internal self-possession of orality. As a result, he never shows the voice in action, never describes it in its exploratory activity. But it is this erasure of voice which, for me, involves him in a misrepresentation of what iambic pentameter rhythmically is, a play of different degrees of accentual promotion and demotion, rather than of accentual substitutions.

Meschonnic equates accentual/stress intensity with semantic intensity (comparing the first line of sonnet 137 - 'Thou blind fool love, what doost thou to mine eyes' - with Hopkinsian sprung rhythm) and thus implies that to diminish stresses is to shy away from the obligations of signifiance. Moreover, he makes an inevitable connection between this loss of (accentual) intensity and the spokenness of verse. For him, the speaking voice slackens rhythmic grip, so that to read an iambic pentameter as if it only had three stresses is to seriously lighten its signifying capacity. Thus, to read the opening line of sonnet 71 , not in Meschonnic's scansion:

No longer mourn for me when I am dead $\quad \mathrm{x} / \mathrm{x} / \mathrm{x} / \mathrm{x} / \mathrm{x} /$ 
No longer mourn for me when I am dead $\quad$ x x / x x / x x /

may indeed be to remove the regular tolling of the bell, and to downplay the self-projection of the subject and the potential pathos in 'No longer'; but, for me, this is not so much a diminution as a shift of expressive means. Sustained iambic recitation evens out pitch and pace, and establishes an inflexible gravity. The three-stress 'rewriting' allows a broadening of pitch-range, encourages self-interruption and variable tempi and introduces a rhythmic movement which is poignantly non-presumptive, apologetic even, an anticipated spectrality.

In the same spirit, where Meschonnic suggests that the sonnet's final couplet reads:

Lest the wise world should look into your moan, / x / / / x x x / And mock you with me after I am gone. $\quad \mathrm{x} / / \mathrm{x} / / \mathrm{x} / \mathrm{x} /$

I would go:

Lest the wise world should look into your moan, $\quad \mathrm{x}$ x / / x / x x x / And mock you with me after I am gone. $\quad$ x / x x x / x x x /

Meschonnic's account strikes me as melodramatic, or unjustifiably self-dramatizing, and promotes the meaning 'mock you along with me' which, although possible, is not, for me, half as much in the sonnet's spirit as 'use me to mock you'. Moreover, he undermines, or begins to undermine, his own arguments against the producers of 'simili-vers', by suggesting that: 
Paradoxalement, regarder le pentamètre iambique comme constitué non de cinq iambes, mais de dix syllables, libère à la fois la métrique et le rythme, et correspond mieux à la réalité du vers, comme rythme du discours, sans oublier la césure, le plus souvent à la même place traditionnelle que dans le décasyllabe français ou dans l'hendécasyllabe italien (de Dante) - la quatrième ou la sixième, parfois la cinquième. ${ }^{18}$

(Paradoxically, to look upon the iambic pentameter as constituted not of five iambs, but of ten syllables, liberates, at a go, both metre and rhythm, and corresponds better to the reality of the line, as rhythm of discourse, without forgetting the caesura, most frequently found in the same traditional position as in the French decasyllable or in the Italian hendecasyllable (of Dante) - after the fourth or sixth syllable, or sometimes the fifth).

This sounds to me like a critical U-turn.

Given this vision of the liberated treatment of the pentameter, of its 'syllabification', and despite his rather misleading account of the caesura, Meschonnic's innate distrust of the individuated voice remains puzzling. It undoubtedly lies partly in the belief that the voice, with its paralinguistic supplementation of text, positively distracts from orality, that it places on orality a surface which is vulnerable to the randomness of circumstance. It leads us away from poetics towards rhetoric, it trains the ear on the textual surface and localized acousticity - 'Écrit ou parlé. Ce dualisme traditionnel empêche de penser cette oralité pourtant toute d'expérience, qui est une oralité-sujet, une oralité-historicité, non plus sa réduction au sonore' ${ }^{19}$ ('Written or spoken. This traditional dualism prevents us from thinking properly about this orality, truly experiential though it is, which is an orality-subject, an orality- 
historicity, and no longer its reduction to the acoustic'). Meschonnic makes it clear, in his comments on the meaning of Mikra, ${ }^{20}$ that reading aloud is to be understood as a collective experience, and that orality and collectivity in reading are for him 'indissociably' combined: 'Ainsi le texte, par son rythme, [...], est avant tout en effet littérature orale, et literature orale cela signifie collectivité' ('Thus the text, by virtue of its rhythm, [...], is in fact, first and foremost, oral literature, and oral literature signifies collectivity'). But Meschonnic is thinking about the reading of a writing, about the establishment of a discourse/a subjectivity in the writing - orality merely provides the letters of credit. We are thinking of something like the opposite, about a writing of a reading, where our reading is undoing, is discomposing, a discourse/a writing, as a necessary prelude to making itself into a discourse.

And yet we might propose that it is, precisely, the mode of reading-contact, and more specifically the paramountness of paralinguistic input, that produces the shift from history to historicity: we imagine a reader for whom text is not to be read in an absorptive manner, as if the answers to questions about vocal delivery are to be found in the text, but in an interrogative and experimental manner, where the experiment is how the reader might immerse him/herself in fruitful experiences of text. One might think for a moment that Dessons and Meschonnic would agree with such a proposition, when they write:

Mais une diction individuelle pourra toujours accentuer, en fonction d'une intention particulière, tel ou tel élément normalement inaccentué, puisque le jeu corrélé de l'accent de groupe et de l'accent prosodique permet un nombre illimité de combinaisons et que tout mot en français est accentuable et désaccentuable. ${ }^{21}$

(But an individual mode of delivery will always be able to accentuate, in line with a particular intention, such and such an element normally without accent, since the correlated play of group accent and prosodic accent allows an unlimited number of 
combinations and since every word in French is both accentuable and disaccentuable).

But they then go on to add the proviso: 'La diction n'est pas pour autant à confondre avec le rythme écrit du discours' (p. 86) ('Vocal delivery is not, for all that, to be confused with the written rhythm of the discourse'). For me, 'rythme écrit' is a contradiction in terms, since rhythm is always deeply involved with the paralinguistic; and it is from the paralinguistic that it derives its multi-dimensionality.

Mode of delivery, then, is, for Dessons and Meschonnic, exterior to the text and not to be confused with the organisation of rhythm. Rhythm is a reality of the text not to be muddied by readerly sentiment. Thus, to speak/read a phrase such as 'il frappe très fort' with an intensifying accent on 'très' would be alien to the rhythm of the text because, as they so disarmingly put it, the accent is not there! (pp. 127-128). This seems to me foolish, and is made more so by Dessons and Meschonnic's having to make rule-governed the prosodic accents they isolate: that is, the accent on group-initial consonants, associated with phonemic repetition; the accent d'attaque, on group-initial consonants and vowels (pp. 137-144); ${ }^{22}$ and the rhythmic and prosodic contre-accent, or sequence of consecutive accentuated syllables. Meschonnic's equation of voice with the invasion of subject-discourse by the caprice of vocal individuation misses the point; for us, the true equation is one between the individual, enunciating voice and an experimental expressivity, an expressivity which is the instrument of epistemological inquiry.

The vocal is the force of the 'facultatif' in the epistemological adventure of reading. As Meschonnic's claims for discourse become more uncompromising, and more tightly interwoven with the other concepts in the set (rhythm, orality, continuity, etc.), so, it seems to me, his opposition to the optional, to the 'facultatif', hardens. The 'facultatif' is the real vocative, the reconfigurable, the negotiable, the translational. But Dessons and Meschonnic 
set their faces against the flexible and any extension of possibilities: 'On ne confondra donc pas le rythme d'un texte avec le sentiment qu'un lecteur peut, subjectivement, et donc arbitrairement, en avoir. [...] Il y a entre les deux notions [rythme, discours] une solidarité fondamentale. Les procédures d'analyse du rythme sont concrètes et positives, elles mettent en évidence une réalité du texte. Cette réalité, on le verra, peut être problématique, mais pour des raisons qui tiennent au texte lui-même, c'est-à-dire qu'une indécision s'explique, se démontre à partir du texte, et non en fonction d'un sentiment du lecteur qui peut, par exemple, être influencé par le sens des mots, [...]' (p. 127) ('The rhythm of the text should not therefore be confused with a feeling that a reader may, subjectively, and therefore arbitrarily, have about it. [...] There is a fundamental solidarity between the two notions [rhythm, discourse]. The procedures for the analysis of rhythm are concrete and positive, they disclose a reality of the text. This reality, as we shall see, can be problematic, but for reasons which relate to the text itself, that is to say that any indecision can be explained, can be demonstrated, on the basis of the text, and not by virtue of a feeling of the reader, who may be influenced by the sense of the words'). Here we find castigated all the threats and irresponsibilities of diction, of 'le vagabondage individuel' (p. 187) ('individual vagabondage'), and more particularly of the ability to find alternative texts within the text: 'La subjectivité toujours recommencée d'un texte est alors confondue avec un subjectivisme qui prend pour un possible du texte un autre texte, celui que le lecteur a dans la tête' (p. 187) ('The ever-renewed subjectivity of a text is thus confused with a subjectivism which regards, as one possibility of the text, another text, the text that the reader has I his/her head').

But this passage (p. 127) and what follows it are disturbing for other reasons. With his emphasis on the present participial force of the 'signifiant', its animation and dynamic, it is odd to find Meschonnic warning us off being 'influencé par le sens des mots'. It is odd, too, that he should condemn the arbitrariness of a reader's feeling, when his enthusiasm for 
Saussure is made up of the arbitrary's being, not a force complicit with convention, but, on the contrary, that which allows us to envisage an infinity of systems all with their own differential networks of relative values.

In the passage that follows (p. 128), Meschonnic further disturbs by observing that rhythmic analysis 'met en jeu l'historicité d'une lecture, c'est-à-dire, à la fois, sa capacité de réénoncer un discours et d'être énoncé par lui' ('puts in play the historicity of a reading, that is to say, at one and the same time, its capacity to re-enunciate a discourse and to be enunciated by that discourse'). This sounds like a forward-moving dialectical process, whereby discourse changes the reader, only to be changed in its turn by the reader. But Meschonnic's order of events also implies that any re-enunciation on the reader's part is immediately scotched by the text's insistence on doing the enunciating. Does this not suggest that the discourse's system is impervious to any self-introjection of an historicized reader, that the historicity of any particular reader is merely an accident of history? This, at any rate, is what the sentence following seems to entail: 'Ce qui implique que le protocole du commentaire soit motivé par l'approche de la poétique de ce texte, qui est la réalisation de son système dans le moment historique d'une lecture particulière' (p. 128) ('Which implies that the protocol of commentary be motivated by an approach to the poetics of this text, which is the realisation of its system in the historical moment of a particular reading'). Here 'the historical moment of a particular reading' sounds like an indifferent consideration as far as the system is concerned.

What, then, is my position on discourse, on the notion of movement in relation to language and on the corporeality of orality? First, the text exists as much by what it makes possible as by what it is; the text is as much in its invisible as it is in its visible; the text from its very conception is multiple, a multiplicity of variants and possible formal itineraries and expressive energies which re-metabolisations will release. In short, a discourse is not just 
susceptible of re-enunciations, as new translators turn to it, bringing new historicities; ${ }^{23}$ a discourse is, in its very being, in the contingency of its own historicity, re-enunciative, or even self-re-enunciating.

I use 're-metabolisation', rather than say 're-configuration', because I want to capture that sense of a transformative body-chemistry, of the way in which a discourse might be invited to re-process its constituents, to re-programme its inner dynamic. And there are two strategies I have in view. The first strategy constantly redisposes text, and thus redisposes its rhythmicity, changes its phrasing and segmentation, its tempi and the nature of its fluency. For example, I translate Apollinaire's 'Ibis' from his Le Bestiaire into a corresponding quatrain of octosyllables, underlyingly trochaic, but with 33 syllables overall and rimes embrassées rather than rimes croisées:

Ibis

$\begin{array}{ll}\text { Oui, j'irai dans l'ombre terreuse } & 3>2>3 \\ \text { O mort certaine, ainsi soit-il! } & 4>4 \\ \text { Latin mortel, parole affreuse, } & 4>4 \\ \text { Ibis, oiseau des bords du Nil. } & 2>2>4\end{array}$

Down into earthy shadows I'll / / x / x / x /

Go. Death's certain, yes, sic fiat, / / / x / / / x

Fatal Latin, dreadful diktat, $\quad$ / x / x / x x /

Ibis, bird of Thoth, bird of the Nile. / x / x / / x x / 
I then recast my quatrain as a sixain with the syllabic profile 6/5/9/4/5/4:

\begin{tabular}{|c|c|}
\hline down into earthy sha- & $/ \mathrm{x} \times / \mathrm{x} /$ \\
\hline dows I'll go. Death's cer- & $\mathrm{x} \times / / /$ \\
\hline tain, yes, sic fiat, fatal Latin, & $\mathrm{x} / / / \mathrm{x} / \mathrm{x} / \mathrm{x}$ \\
\hline dreadful diktat, & $/ \mathrm{x} \times /$ \\
\hline ibis, bird of Thoth, & $/ \mathrm{x} / \mathrm{x} /$ \\
\hline bird of the Nile. & $/ \mathrm{x} \times /$ \\
\hline
\end{tabular}

Then I recast it again, this time as a nonet, with the syllabic profile 3/2/5/4/4/4/5/4/2, such that a calligrammatic depiction of a seated ibis, begins to emerge:

down into
earthy
shadows I'll go.
certain,
fiat,
Latin, $\quad$ dreatal
diktat,
Ibis, bird
of Thoth, $\quad$ bird of
the Nile.

The second strategy changes form or structure in order to reveal the unused, or virtual, or invisible, stock of variants which might have been real variants, or are simply possible 
solutions called forth by formal requirements. ${ }^{24}$ For example, I select an octosyllable from Baudelaire's 'Le Chat', and transform it, first into a decasyllable, and then into an alexandrine:

Cette voix, qui perle et qui filtre $\quad 3>2>3$

Cette voix lisse, et qui perle et qui filtre $\quad 4 / / 3>3$

Cette voix enfin calme, et doucement perlée $\quad 3>3 / / 4>2$

Moving in the opposite direction, I transform an alexandrine from Baudelaire's 'Harmonie du soir', first into a decasyllable, and then into an octosyllable :

$$
\begin{array}{rc}
\text { Le soleil s'est noyé dans son sang qui se fige } & 3>3 / / 3>3 \\
\text { Le soleil se perd dans son sang figé } & 3>2 / / 3>2 \\
\text { Soleil qui tombe ensanglanté } & 4(2>2)>4
\end{array}
$$

By these means, I begin to lay bare rhythmic configurations, syntactic structures, a vocabulary, which might well have played a part in Baudelaire's compositional ruminations, but which were made invisible by other choices.

As far as the movement of language is concerned, we need to remember that the voice distributes the sounds of phonemes, to maintain speech-flow, where the printed language segregates them. Stephen Handel points out, for example, that 'The spelling of the word cat is "c" followed by "a" followed by " $t$ ". If, however, we try to cut out the "c" part from a tape recording, no unique section can be found. The "c" permeates the entire word acoustically, albeit not perceptually' ${ }^{25}$ and further generalises: 'The production system must cheat in order to get all the sounds out rapidly: movements appropriate to several successive sounds must be 
made simultaneously, and movements necessary to produce future sounds must be started early enough to ensure that the vocal tract will be in the correct position to make those sounds when they are required' (p. 134). This all helps us to understand that the movement of which we speak is a kind of porosity or permeability, that it is created by morphing rather than by choice, by the volatilities and proliferation of sense rather than by the objectives and identities of meaning. This is all part of doing justice to the inner duration of discourse, which is interwoven with that of the reader/translator; in my own translations, the reader's durational presence is often marked by changing typefaces (voice-tones) and handwritten associations (Fig. 1: 'Travellers Travelling', a translation of Baudelaire's 'Bohémiens en voyage'). And this duration is both rhythmic and experiential flux and an ongoing relationship of reciprocation with the source discourse. The printed target text is not therefore to be perceived as a stasis, as an achieved condition, however momentary; but rather as a cross-section of ongoing interactive durations, which entails the development of new forms of scansion. ${ }^{26}$

About corporeality/materiality I want only to say: that the production of discourse involves all that is corporeal in paralanguage and kinesics; that the participation in the rhythms of discourse involves kinaesthetics; that the associative ramifications of discourse involve synaesthetics, intersensory variation, metamorphosis. And not only that. The body of the reader participates, too, in the reading environment, and the page, or book, as object interacts with the larger material environment, is subject, indeed vulnerable, to it; the text might, for example, be intruded upon by sundry realia (Fig. 2), or torn and creased (Fig. 3), such that its existence, its presence, its spatiality and temporality, its significance even, all derive to some degree from its changing situatedness in the quotidian (Fig. 4: another version of 'Travellers Travelling', covered in contact prints of the text in multiple domestic environments). 
Rhythm, as Meschonnic himself insists, is a political force in the poem. Rhythm serves principles which subvert metre; it counters metre's striated space with smooth space, the quantitative with the qualitative, the mono-dimensional with the multi-dimensional, the homogeneous with the infinitely variable. Rhythm acts as a critique of the sign by acting against codes, against the surveillance of the signifier by the signified, against all forms of binariness. It is the force of historicity against that of history, the ability of small, situated acts, in the very flux of time, to compel history to abandon its accumulated certainties. But translation, too, for much the same reasons, but with consequences for rhythm, is a political force. It is the route by which the citizen-reader inserts him/herself, as fifth columnist, into the canonical and authoritative text. Translation introduces an intercultural or multi-cultural interstitial space in which all is movable, in which boundaries disappear, in which all kinds of promiscuity can take place; these are fields of linguistic energy without impediments, where quantity is not answered by quantity, but assessed as quality, and where the variably heterogeneous and multi-dimensional ensure that different elements can generate metamorphic continuities out of the discontinuous jumps of montage. This is why we canvass a translation which translates from the linear to the tabular. And essential to this fruitful subversion is that we think of text not so much as a textual matrix which makes multiple readings possible, allowable, but rather as an inadequate transcription of any particular reading. Reading is always in excess of text. It is why translation must remain firmly experimental; and the experimental is what Meschonnic's centripetal thinking makes alien. 
1. As Meschonnic puts it, in La Rime et la vie (Lagrasse: Verdier, 1989) : 'Celle-ci [la théorie du langage] est en train de passer, non sans résistance, des catégories de signe, de sens, d'énoncé, toutes catégories de la langue, à des catégories spécifiques du discours, telles que l'énonciation, la signifiance, le rapport du langage au corps. Renouvellement de la conception du sujet par le renouvellement de celle du rythme' (p. 236) ("This [the theory of language] is in the process of shifting, not without resistance, from the categories of sign, meaning, énoncé, all categories belonging to langue, to categories specific to discourse, such as énonciation, signifiance, the relation of language to the body. A renewal of the conception of the subject by the renewal of the conception of rhythm').

2. In Traité du rythme: Des vers et des proses (Paris: Dunod, 1998), Dessons and Meschonnic define 'récitatif' as follows: '[...] ce que les mots font entre eux par les éléments qu'on appelait leur matérialité. [...] Le récitatif est alors la manière dont une subjectivité, qui n'est pas d'ordre psychologique mais proprement poétique, organise cette signifiance. Le récitatif est une subjectivation’ (p. 170) ('[ ...] what words do among themselves with elements of what used to be called their materiality. [...] Recitative is thus the way in which a subjectivity, of a truly poetic rather than a psychological kind, organizes this significance. Recitative is a subjectivation'). Elsewhere, in Éthique et politique du traduire (Lagrasse: Verdier, 2007), Meschonnic expresses it a little differently: 'C'est ce que j'appelle le récitatif, par quoi j'entends toute la sémantique sérielle dans le continu du discours, et qui court à travers le récit, qui est l'énoncé' (p. 114) ('It is what I call the recitative, by which I mean the whole serial semantics in the continuum of discourse, which runs through the narrative, which is the enunciated').

3. Lucie Bourassa (Henri Meschonnic: Pour une poétique du rythme (Paris: Bertrand- 
Lacoste, 1997)) brings this danger to our attention in an early commentary: 'Ensuite, elle [cette poétique] déploie un appareil conceptuel fondé sur le postulat d'implication réciproque des notions, notions qui ainsi semblent s'enchevêtrer' ( $p$. 9) ('Next, it [this poetics] deploys a conceptual apparatus based on the postulate of the reciprocal implicatedness of the notions, notions which thus seem to be interwoven'). Further on she adds: 'Les concepts fondamentaux de cette théorie: sujet et historicité; discours et poétique; prosodie, signifiance, rythme et oralité; traduction, rapport et décentrement (pour ne nommer que ceux-là) se présupposent mutuellement, si bien que le lecteur doit faire un effort pour ne pas rester prisonnier d'une circularité apparente' (p. 10) ('The fundamental concepts of this theory : subject and historicity; discourse and poetics; prosody, signifiance, rhythm and orality; translation, relation and off-centring (to name just these) are mutually presupposing, such that the reader has to make an effort to avoid being caught in an apparent circularity').

4. I think particularly of observations such as: 'Die Übersetzung ist die Überführung der einen Sprache in die andere durch ein Kontinuum von Verwandlungen. Kontinua der Verwandlung, nicht abstrakte Gleichheits- und Ähnlichkeitsbezirke durchmißt die Übersetzung' ('Über Sprache überhaupt und über die Sprache des Menschen', Gesammelte Schriften II, I, edited by Rolf Tiedemann and Hermann Schweppenhäuser (Frankfurt am Main: Suhrkamp Verlag, 1977), pp. 140-157 (p. 151)). ('Translation is [the transfer] of one language into another through a continuum of transformations. Translation passes through continua of transformation, not abstract areas of identity and similarity' ('On Language as Such and on the Language of Man', Selected Writings I: 1913-1926, edited by Marcus Bullock and Michael W. Jennings (Cambridge, MA: Belknap Press/Harvard 
University Press, 1996), pp. 62-74 (p. 70)). Bergson, one might argue, suffers something of the same fate as Benjamin in Meschonnic's appraisal (e.g. Critique $d u$ rythme: Anthropologie historique du langage (Lagrasse: Verdier, 1982), pp. 17683): what Bergson has to say that is crucial about inner duration and movement is disqualified, according to Meschonnic, by his cinematic view of language, and his dislocation of language from the speaking/writing subject (La Rime et la vie, revised and enlarged edition (Paris: Gallimard, 2006), p. 377).

5. Poétique du traduire (Lagrasse: Verdier, 1999), p. 196.

6. Les États de la poétique (Paris: PUF, 1985), p. 130.

7. Traité du rythme, p. 165. It should be said, however, that Dessons and Meschonnic defend themselves against the charge of over-accentuation: 'La suraccentuation n'est pas un cas exceptionnel du rythme. C'est un phénomène ordinaire de tout discours; aussi ordinaire que le rythme lui-même, puisque le rythme est cette accentuation même' (Ibid., p. 151) ('Over-accentuation is not an exceptional instance of rhythm. It is a phenomenon common to all discourse; as common as rhythm itself, since rhythm is this very accentuation'). In support of their own view, Dessons and Meschonnic also call upon Ezra Pound's 'Language charged with meaning to the utmost degree' (Ibid., p. 172).

8. Poétique du traduire, p. 220; see also p. 191.

9. I am doubtful of Meschonnic's ability to square his own declarations about the selfsustaining nature of discourse, its unique 'systematisation' - 'Système (d'une œuvre). L'œuvre (chaque œuvre) comme totalité caractérisée par ses propres transformations, qui dependent de ses lois internes' (Pour la poétique (Paris: Gallimard, 1970), p. 175) ('System (of a work). The work (each work) as a totality characterized by its own transformations, which depend on its internal laws') - and 
the ways in which discourse renews our relationship with the world (La Rime et la vie (Lagrasse: Verdier, 1989), p. 108) and is continuous with other practices of language (Politique du rythme. Politique du sujet (Lagrasse: Verdier, 1995), p. 17).

10. This is particularly evident in his extended critique of Jaqueline Risset's translation of Dante's Divine Comedy (1985) (Poétique du traduire, pp. 203-213).

11. Translation naturally brings into existence the mechanism of back-translation, by which the source text turns out to be an 'inadequate' account of the target text, by which notions of textual priority are thrown into doubt, and suggest constantly selfadjusting oscillation, or unresolved dialectical exchange as the only fruitful modes of reading.

12. For a discussion of this distinction, see Poétique du traduire, pp. 95-6.

13. Ibid., p. 180.

14. Euvres complètes II, edited by Bertrand Marchal (Paris: Gallimard, 2003), p. 206.

15. Poétique du traduire, p. 194.

16. Ibid., pp. 258-307.

17. Ibid., p. 261.

18. Ibid., p. 262.

19. Politique du rythme, p. 116.

20. Les États de la poétique, pp. 51-52.

21. Traité du rythme, p. 86.

22. Is this any more than a way of converting the spoken ('accent d'insistance') into the oral ('accent prosodique')? Meschonnic always insists on the non-systematicness of the 'parlé'. I should also say that I am not convinced by Dessons and Meschonnic's argument that following, ostensibly assonating vowels are not involved in prosodic accents connected with the repetition of word-initial consonants; they maintain: 'La 
primauté est donnée au phonème consonantique. La voyelle, en effet, est trop instable pour porter l'accent, puisqu'elle change de valeur selon la consonne d'appui' (p. 138) ('Primacy is given to the consonantal phoneme. The vowel is, in fact, too unstable to carry the accent, since it changes in value according to the consonant that precedes it'). It seems to me natural that vocalic kinship, even if it does not constitute absolute identity, is a powerful endorsement of the accentuation of preceding similar consonants, and will naturally draw onto itself some of that accentuation, since vowels are the natural home of accentuation. Besides, given Meschonnic's promotion, after Saussure, of discourse as a complex weave of relative, differential values, it seems natural that accentual highlighting should be a tool in bringing variation of such values to consciousness.

23. Whatever Meschonnic claims about the 'ré-énonciation' of discourse, there is very little evidence in his own criticism of translations that the maintenance of the structures (rhythm, prosody, etc.) of the source text are anything less than paramount. Translation, for Meschonnic, never comes very close to transposition; 'correspondance' (Poétique du traduire, p. 341) is more his word.

24. Meschonnic does not consider that those kinds of textual manipulation and permutation practised by the likes of Raymond Roussel, the Surrealists and Oulipo are genuine manifestations of a text's natural susceptibility to change; they are merely jeux d'esprit at the level of the linguistic mechanics of a text rather than of discourse (Poétique du traduire, pp. 169-170). I see no reason to agree.

25. Listening: An Introduction to the Perception of Auditory Events (Cambridge, MA: MIT Press, 1989), p. 2.

26. See Clive Scott, The Work of Literary Translation (Cambridge: Cambridge University Press, 2018), pp. 221-38. But does Meschonnic ever properly ask how 
rhythm is to be apprehended? Bourassa provides an explanation (Henri Meschonnic, p. 86): 'Cela s'explique en partie par le fait que le rythme pour lui ne se réduit pas à ce qui est perceptible, mais au contraire, se situe dans “l'infime, l'incertain, l'inaperçu" (Politique du rythme, p. 155) et requiert une "écoute plus fine du langage" (Ibid., p. 153): "Le langage à contrainte maximale d'un texte littéraire a une force qui joue trop de tous les signifiants pour qu'on puisse même en discerner tous les éléments"' (Ibid., p. 192)' ('That is to be explained partly by the fact that rhythm, for him, cannot be reduced to what is perceptible, but, on the contrary, is located in "the minute, the uncertain, the unnoticed" (Politique du rythme, p. 155), and requires a "more refined listening to language" (Ibid., p. 153) : "The language of a literary text, with its maximal constraint, has a power which brings all its signifiers too much into play for one to be able to discern all its elements" (Ibid., p.192)'). 